\title{
Turkish Foreign Policy Toward the Algerian War of Independence (1954-62)
}

\section{Eyüp Ersoy}

To cite this article: Eyüp Ersoy (2012) Turkish Foreign Policy Toward the Algerian War of Independence (1954-62), Turkish Studies, 13:4, 683-695, DOI: 10.1080/14683849.2012.746440

To link to this article: http://dx.doi.org/10.1080/14683849.2012.746440

\section{册 Published online: 13 Dec 2012.}

Submit your article to this journal $[\pi$

Џlll Article views: 264 


\title{
Turkish Foreign Policy Toward the Algerian War of Independence $(1954-62)$
}

\author{
EYÜP ERSOY \\ Department of International Relations, Bilkent University, Bilkent, Turkey
}

\begin{abstract}
Turkish foreign policy toward the Algerian War of Independence (1954-62) was construed as persistent Turkish endorsement of official French positions generating abiding resentment among the states of the Third World, especially Arab states, and understandably in Algeria, which was to elicit backlashes from the Third World states thereafter consequently causing substantial complications in Turkish foreign policy. Stressing the importance of incorporating nonmaterial and ideational factors in analyses of foreign policy, two arguments are put forward in this article for an accurate explanation of Turkish foreign policy toward Algerian War of Independence. First, it was the conception of the West, defined not only in strategic or military terms, but also in ideational and civilizational terms that induced Turkish policymakers to adopt insular policies regarding Algeria. Second, a "temporal contextualization" of Turkish foreign policy during the Algerian War of Independence is required for a proper understanding of Turkish foreign policy toward the Algerian War of Independence.
\end{abstract}

Turkish foreign policy toward the Algerian War of Independence (1954-62), or Guerre d'Algérie, both in public declarations, in discussions and related voting in the United Nations (UN) General Assembly over the issue of Algerian selfdetermination and independence was construed as persistent Turkish endorsement of official French positions both by the Turkish, French, and Algerian politicians and, accordingly, generated abiding resentment among the states of the Third World, especially Arab states, and understandably in Algeria, in that early period of the Cold War. Turkish Western-oriented foreign policy attitude during the period was to elicit backlashes from the Third World states thereafter, which consequently caused substantial complications in Turkish foreign policy.

In the mid-1960s, Turkish foreign policy-makers bitterly realized the existence and the extent of Turkey's isolation in world politics when Turkey abruptly encountered the exigency of obtaining international support. The dispute over the future of Cyprus came to the forefront of Turkish foreign policy in a short period of time, and in the

Correspondence Address: Eyüp Ersoy, Department of International Relations, Bilkent University, 06800 Bilkent, Ankara, Turkey. Email: eersoy@bilkent.edu.tr 
absence of unequivocal support from its traditional Western allies over the issue, and in fact experiencing the adversity of the Johnson Letter, the support of the Third World states became crucial for Turkey, especially in the UN. At this juncture, the legacy of its foreign policy toward the Third World haunted Turkey and was to beleaguer its foreign policies for a long time to come.

Turkey's attitude toward the Algerian War of Independence constitutes an interesting case. In December 1958, in the voting of a resolution calling for negotiations between France and Gouvernement Provisoire de la République Algérienne (GPRA), in the UN General Assembly, Turkey and the US both abstained. Both the French and Algerian leaders construed the abstention of the US as a loss of support for the French position. While for the French UN representative, as Connelly indicated,

there is little doubt that it [Front de Libération Nationale (FLN)] has gained a good deal on the international level and in all the countries of the world where it has sent missions, especially the United States and the United Nations

for Ferhad Abbas, the president of the GPRA, "the US abstention was 'incontestably a success ... encouraging the Algerians' efforts to exploit the escalating 'war of nerves' between the putative allies". ${ }^{1}$ Interestingly enough, on the other hand, the Turkish abstention was construed as diplomatic support for the French position by both the French and the Algerian leadership as their subsequent private and public statements, appreciative on the French part and resentful on the Algerian part, demonstrate. This discrepant interpretation of the same action, abstention in the voting, can be attributed to the policy expectations of the parties in terms of Turkish foreign policy since, prima facie, the parties would have expected a rather explicit pro-Algerian Turkish diplomatic position for a couple of reasons.

First of all, Turkey is the first country that waged a triumphant war of independence against colonial powers of the time. During the Turkish War of Independence (191923 ), there was widespread interest and support, if not material but moral only, among the Turkish leadership for anti-colonial and national independence movements abroad. For example, in an interview he gave to The New York Herald on January 23, 1923, Mustafa Kemal Paşa expressed that permanent peace and disarmament is achievable "on the sole condition that the statesmen of Great Powers learn to admit that all nations, big or small, have equal rights to independence and development". ${ }^{2}$ To Mustafa Kemal Paşa, the cause Turkey defended was the cause of all oppressed nations, and Turkish success in its struggle would serve as a model for the struggles of "Eastern" nations for independence. ${ }^{3}$ In fact, Turkish success in repudiating colonial rule and tutelage through armed struggle had repercussions abroad.

In China, for example, in the 1920s there were serious disagreements between the Chinese government led by the Chinese nationalists (Kuomintang/KMT) and the imperial powers over issues pertinent to Chinese sovereignty, such as tariff autonomy and extraterritoriality. According to the diplomatic historian Stephen P. Duggan, in 
the discussions between the parties over such contentious issues, one of the two events "which greatly stiffened the attitude of the Chinese nationalists towards the powers" was "the cavalier manner with which the Turkish Nationalists had treated the Powers and practically compelled them to sign the Treaty of Lausanne". 4

However, two decades later, in its foreign policy, Turkey opted for an alignment with France against the Algerian independence movement, which espoused virtually the same anti-colonial nationalist ideology, if not methods, of Turkish struggle for independence while the leaders of the Algerian national liberation movement invoked, at least at the onset of the movement, the Turkish experience. Messali Hadj, as an example, who was a prominent personality especially in the early phase of the independence movement, stated in an informal meeting with the Turkish journalist Faruk Demirtaş, in 1951 that Mustafa Kemal Atatürk was an inspiration for the Muslim world and they tied the path of their movement to the path of Atatürk. ${ }^{5}$

The second reason that would make Turkey's attitude toward the Algerian War of Independence a wonder is the fact that Algeria was under Ottoman rule until French forces invasion in 1830; it was not directly ruled from Istanbul, and was a tributary state tough. Furthermore, the Turkish struggle for independence was in part carried out against occupying French forces in southern Turkey. ${ }^{6}$ In other words, during the Algerian War of Independence, contrary to one would have expected, Turkey affiliated its policy against the independence movement of a people once under its rule with the policy of a colonial state against which Turkey carried out its own independence movement, though Algeria was not a French colony but was constitutionally a part of France. As the third reason, even though religion was not a criterion in foreign policy decision-making in the Cold War, the parties would have expected a Turkish demonstration of solidarity with the Algerian independence movement on religious grounds as the widespread discourse of jihad in Algeria and the Algerian mujahideen in the Turkish media and among the Turkish public would have suggested.

This line of reasoning and the subsequent expectation of Turkish support and the consequent disillusionment with its policy were starkly evident in the somewhat acrimonious response of Houari Boumediène to the question of a Turkish journalist in June 1965, just after the bloodless coup he staged that toppled Ahmed Ben Bella and brought him to power. As one of the most important leaders of the Algerian national liberation movement who held several high-ranking posts within the Front de Libération Nationale (FLN), and ultimately became the President of Algeria in 1965, Boumediène's response can be considered representative of the general perception among the leadership of FLN of the Turkish policy. Turkish journalist Lütfü Akdoğan was curious about the relations of Algeria with Turkey in the future. Boumediène responded:

We are resentful of and offended by Turkey. This does not mean that we will declare war against Turkey. As you know, Turkey has always sided with the 
French in our struggle. We suffered a great deal in the United Nations. But in fact, Turkey is Muslim and ruled here for 300 years. $^{7}$

However, contrary to the expectations of the Algerian leadership, and, in general, to the frustration of Third World states and at the expense of alienating them, Turkey proved itself as a staunch ally of the West, and as a result, of France during the Algerian War of Independence. This article addresses the underlying dynamics of Turkish policy during that period and attempts to provide a general framework for an understanding of Turkish foreign policy toward the Algerian War of Independence. The key to this attempt is to discuss the conditionality of Turkish foreign policy at the time, in general, and the temporality of Turkish foreign policy vis-à-vis the Algerian War of Independence, in particular.

Turkey's heavily and exclusively Western-oriented foreign policy in the aftermath of World War II made all its relations with non-Western parts of the world conditional on its relations with the West. This might either be a deliberate policy of Turkish policy-makers or a spontaneous derivative of Cold War politics. Conditionality influenced Turkish policy toward the Algerian War of Independence in two ways. First, since France was a member of the West, and its putative embodiment the NATO, Turkish policy-makers decided to align Turkey with France, which was considered a fellow European state. Second, this conditionality affected understandings and attitudes of Turkish policy-makers toward the decolonization process, and shaped Turkish foreign policy with regard to it. The Algerian national liberation movement was a part of three intertwined decolonization processes, that is, French, African, and global, and thus Turkish policy toward it was susceptible to the Turkish policy toward the decolonization process.

With regard to temporality, the Algerian War of Independence took place between 1954 and 1962. This was a period between Turkey's entry into NATO in 1952 and the dispatch of the infamous letter of the US President Lyndon Johnson in 1964. These constituted two temporal junctures, which arguably characterized the advent and the end of the most Western-oriented period of Turkish foreign policy in the Cold War.

In the first part of the article, a detailed account of Turkish foreign policy toward the Algerian War of Independence is provided. In the second part, the conditionality issue is discussed in great detail, and it is contended that it was the conception of the West, defined not only in strategic or military terms, but also in ideational and civilizational terms that induced Turkish policy-makers to adopt insular policies regarding non-Western "parts" of the world. In brief, it was not only the state of affairs but also the state of mind that determined Turkish foreign policy toward the Algerian War of Independence. In the third part, the temporality issue is addressed by discussing the significance of Turkey's entry into NATO in 1952 and the Johnson Letter of 1964 for Turkish foreign policy orientation in the Cold War, and contends that this sort of a "temporal contextualization" is required for a proper understanding of Turkish foreign policy toward the Algerian War of Independence. The conclusion stresses the importance of incorporating non-material and ideational factors in analyses of foreign policy. 


\section{Algerian War of Independence and Turkish Policy}

It is generally accepted that the Algerian War of Independence began on November 1, 1954 when the FLN rebels launched several attacks in various parts of Algeria against a wide array of civilian and military targets, and when the proclamation of the FLN was distributed in pamphlets across Algeria and in radio transmissions across the region calling for “indépendence nationale par la restauration de l'Etat algérien souverain démocratique et social dans le cadre des principes islamiques". ${ }^{8}$ However, grandiose the proclamation was, these initial attacks were "largely unsuccessful, neither causing severe damage nor arousing much fervor among Algerian Muslims". ${ }^{9}$ Still, the French reaction was zealous as the Mendès-France Government in France was immediately incontrovertible in its condemnation of the revolt, and its resolve to repress it. On November 5, François Mitterrand, Minister of the Interior in the Mendès-France administration declared: "Algeria is France; from Flanders to the Congo there is only one law, one nation, one parliament. The Constitution wills it so, we will it so ... La seule négotiation, c'est la guerre [War is the only negotiation]". ${ }^{10}$ On November 12, Mendès-France addressed the French Assembly unequivocally

One does not compromise when it comes to defending the internal peace of the nation, the unity and the integrity of the Republic. The Algerian departments are part of the French Republic... Between them and metropolitan France there can be no conceivable secession ... Ici, c'est la France! [Here/Algeria, this is France]. ${ }^{11}$

With the action of the FLN and the reaction of France, both equally fervent and intransigent at this stage, a vicious cycle of revolutionary war commenced in Algeria.

The clashes between the FLN rebels and the French forces immediately found repercussions in the Turkish media. The tone of the news was pro-Algerian as the rebels were referred to as nationalists and, by stressing the French use of heavy weaponry; an excessive use of force by France was implied. ${ }^{12}$ It was reported, for example, on November 22 that "nationalists surrounded by the French paratroopers around the Algeria-Tunisia border succeeded in breaking the encirclement with a great deal of dexterity and caused heavy casualties on the French". ${ }^{13}$ A couple of months after the outbreak of the clashes in Algeria, a French parliamentary delegation visited Turkey. In a press conference, the head of the delegation, Gaston Palewski, explained, among others, the French position on Algeria to the Turkish audience that the French were against granting independence to the masses of people that had yet to achieve a character of nationhood and this was against justice. Responding to a question of a journalist about the proper designation of "mujahideen" fighting in Algeria, a member of the delegation stated that the fighters were brigands in a small area and yet they considered any riot a rebellion in terms of the integrity of France. ${ }^{14}$

One of the "objectifs extérieurs" of the FLN in its proclamation was the "internalisation du problème algérien" and to that end while continuing its military struggle in Algeria, the FLN was making persistent efforts in its diplomatic struggle in world 
politics. As its "most outstanding feat of internalization", the FLN achieved an invitation to attend the Bandung Conference of April 1955 of the Non-Aligned Movement representing the emerging Third World, which "adopted unanimously an Egyptian motion proclaiming Algeria's right to independence, and called upon France to implement this forthwith". ${ }^{15}$ With this diplomatic success, the road to the UN was opened for the FLN. In September 1955, the Algerian problem was to be formally inscribed on the agenda of the General Assembly by a single vote. Turkey, among the other 26 states, voted against the petition while 27 states voted in favor of it and five states abstained. ${ }^{16}$

With Morocco and Tunisia gaining "independence within interdependence" in February 1956, the prospects for Algerian independence for the FLN, increased, and the FLN, while continuing the guerrilla war in the countryside, decided to accelerate the process by bringing the fight to cities ushering in a new and savage episode in the rebellion that was to be called "the battle of Algiers". This bloody episode was another step in the internalization of the Algerian problem since, as Ruedy contends, the battle of Algiers

riveted world attention for the first time upon the Algerian struggle and ... for the first time, many of its issues home to the public in France. In the long run, international pressures and a disillusioned French public opinion would be the key factors forcing the French state to accept Algerian independence. ${ }^{17}$

However, the Turkish policy-makers had no interest in pressuring France. On the contrary, in his meeting with the Turkish Prime Minister Adnan Menderes on December 20, 1957, the French Prime Minister Felix Gaillard thanked his Turkish counterpart for Turkish attitude on the issue of Algeria. ${ }^{18}$ On the other hand, the FLN for the first time asked for the Turkish assistance in achieving independence through a message delivered to the Turkish Embassy in Cairo and requested that Turkey, as a member of the Baghdad Pact, use its influence on France. ${ }^{19}$

The political instability of the Fourth Republic culminated in the return of Charles de Gaulle to power that was to cause a massive setback for the FLN since, for example,

If de Gaulle were to follow this [statements of true equality among citizens] with a massive appeal to the battered, disillusioned but still extant "third force" of Muslims, then this could only present the FLN. with the gravest menace to its prestige and war aims. ${ }^{20}$

While the situation in Algeria was not promising for the FLN, the Turkish public was sanguine about Algerian independence. One commentator argued that while the French had not comprehended the fact that the policy of colonization became obsolete, the Algerians had already understood what independence was and thus destined to achieve it. ${ }^{21}$ 
Facing isolation in the international arena due to the constant efforts of de Gaulle to that end, the FLN decided to intensify the struggle of international recognition, and in a press conference in Cairo on September 19, 1958, it announced the formation of a provisional government, the GPRA, with Ferhad Abbas its president. Accordingly, the Algerian national liberation movement entered a new phase as several states immediately extended diplomatic recognition, including all the Arab states except Lebanon, plus China, North Vietnam, North Korea, and Indonesia. ${ }^{22}$ Another step was the UN General Assembly debate in December 1958 on a resolution recognizing the right of the Algerian people to independence and calling for negotiations between "the two parties". Even though the resolution failed to obtain the requisite two-thirds majority, it was considered a considerable success for the GPRA since 34 states supported it while only nineteen states rejected it; 28 states abstained. Turkey decided to abstain in the voting. ${ }^{23}$

Now, it was France's turn to face isolation in the international arena and so as to preclude it de Gaulle declared on September 16, 1959 that "after peace had been restored, Algerians would have a right to self-determination" and his preferred solution to the Algerian problems was a "government of the Algerians by the Algerians relying on French assistance and closely united with France". ${ }^{24}$ De Gaulle's proposals were welcomed in France on October 16, the French Parliament passed a vote of confidence by a huge majority. De Gaulle's proposals were also welcomed in the Turkish public. Sami Kohen, a commentator in the daily Milliyet, contended that de Gaulle's plan constituted an important step toward the settlement of "the formidable" issue insofar as the two parties relinquish a narrow outlook and resolve to end this dispute with "good will and understanding". ${ }^{25}$ On December 12, 1959, another "Afro-Asian resolution recommending negotiations between Algeria and France failed in the UN General Assembly by a vote of 35 to eighteen, with 27 abstentions". ${ }^{26}$ Turkey again abstained in the voting. ${ }^{27}$

In May 1960, the Menderes government in Turkey was toppled by a military coup whose immediate effect on Turkish foreign policy was arguably minimal. "The only visible foreign policy modification of the military junta was an attempt to improve relations with the Arab countries, and a desire to establish closer contacts with the newly emerging nations". ${ }^{28}$ Change in the rhetoric of Turkish foreign policy toward the Third World was visible. Selim Sarper, the new Turkish foreign minister and also a former Turkish representative to the UN, stated in September 1960 "Turkey belongs to the Asia-Africa bloc and always supports the case of these nations within its commitments". ${ }^{29}$ In addition, the new Turkish government proposed mediation on "the Algerian issue", which was to be declined by the French government. ${ }^{30}$ The Turkish President Cemal Gürsel, on the other hand, in an interview in Cairo, announced that he would support the principle of self-determination for Algeria. ${ }^{31}$

In accordance with the policy change, Turkey voted on December 19, 1960 in favor of the UN General Assembly Resolution 1573 on the Question of Algeria recognizing the right of the Algerian people to self-determination and independence, and "the imperative need for adequate and effective guarantees to ensure the 
successful and just implementation of the right of self-determination on the basis of respect for the unity and territorial integrity of Algeria". ${ }^{32}$ However, this was not a radical change since Turkey abstained in the voting of a paragraph calling for an internationally supervised referendum in Algeria, which failed by a single vote. ${ }^{33}$ Still, Turkish endorsement of a pro-Algerian position was welcomed by, for example, the university students from Arab countries studying at İstanbul University who announced that they followed and approved with great pleasure "the understanding of right and independence" in Turkish policy toward Algeria. ${ }^{34}$

Finally, in line with the provisions of the Evian Accords signed by the French government and the GPRA on March 18, 1962, a referendum on the independence of Algeria was held in June and July 1962 both in France and in Algeria in which electorates voted in favor of independence; a position that was also promoted by the Turkish media prior to the referendum. ${ }^{35}$ The GPRA declared July 5 as the day of independence and with the UN Security Council (176) and General Assembly (1754) resolutions, Algeria became an independent state, recognized internationally.

\section{Turkish Policy Toward "The Algerian Question" Revisited}

Foreign policy of the Menderes government toward the Algerian national liberation movement, which was to be referred as the Algerian War of Independence, was unanimously criticized by commentators of different persuasions and scholars of Turkish foreign policy. A left-wing author contended in 1968 that the attitude of the leaders of Democratic Party toward the Algerian problem was utterly "disgraceful" as the Turkish abstentions in the UN General Assembly, for the author, was tantamount to align itself with imperialism and capitalism, and was actually "an ideological betrayal". ${ }^{36}$ For two Turkish scholars, it is evident that the attitude of the Menderes government toward the war of independence Algeria waged against France dealt a heavy blow to Turkey's relations with the states of the Middle East region. ${ }^{37}$ Algerians have been critical of the Turkish policy as well. Ferhad Abbas, the President of the Algerian Assembly, resentfully told a Turkish journalist in the early 1963 that Turkey "left them alone in despair" when they needed Turkey's help the most. ${ }^{38}$ Even for the subsequent Turkey policy-makers, Turkey's abstention to lend explicit diplomatic support to the Algerian position was a mistake. In his visit to Algeria in February 1985, the Turkish President Turgut Özal publicly criticized the decision of the Menderes government to abstain in the UN General Assembly votings, especially that of 1958 :

In that time, this sort of a behavior was made. We cannot excuse not behaving in line with the will of our people. Further, I am of the conviction that accepting our mistake in that matter is a virtue. My hope is that the eternal friendship realizes a rapprochement between the governments as well. ${ }^{39}$

All criticism unequivocally contend that it would have been better, for Turkey or for Algeria or for both, that Ankara extended direct and explicit diplomatic support to the 
Algerian position, especially in the UN General Assembly. However, Turkey's heavily and exclusively Western-oriented foreign policy in the aftermath of World War II made all its relations with non-Western parts of the world conditional on its relations with the West, whether this was the deliberate policy of Turkish policymakers or a spontaneous derivative of Cold War politics. During this period, as Aydın argues “Turkey's relations with the Middle Eastern Arab countries, and Third World states in general, were literally an extension of its Western-dependent foreign policy". 40 Therefore, the strategic outlook of the Turkish policy-makers was dominated by the concerns of the Western alliance, rather than by strictly national concerns. For example, in the London Conference of 1956 convened as a response to the nationalization of the Suez Canal Company by Egypt, Turkey endorsed US, Britain, and France policies putting it in a difficult position in its relations with the non-Western world when Britain and France embarked on the Suez Campaign in late October $1956 .^{41}$

More important was the consolidation of the propensity in foreign policy thinking to construe world affairs not from a perspective of national thinking but from a perspective of the thinking of "the others", be them allies or adversaries. This same propensity was conspicuous in Turkish policy during the Bandung Conference of April 1955. With respect to the Algerian War of Independence, for İhsan Sabri Çağlayangil, Turkish Minister of Foreign Affairs in three terms between 1965-71, 1975-77, and $1977-78$, in the voting of 1958 Turkey was in a difficult position:

If Turkey had said yes, it would have consented to the separation of the territory of a NATO member, friend, and allied country, if it had said no, it would have betrayed its brothers waging a war of independence against the occupier. Abstaining appeared as the lesser of two evils. ${ }^{42}$

The underlying reasoning in this statement of a former Turkish Foreign Minister is characterized by an absence of rational cost-benefit analysis for Turkey's objectives, but an analysis in terms of the costs and benefits of others. In short, the Westernoriented Turkish foreign policy in time became Western-dominated, inducing the Turkish foreign policy-makers to act in world politics not as Turkish but purely as Western. On a related point, Aydin asserts that

Turkey's active role in the creation of such alliances as the Baghdad Pact and the Balkan Treaty which gained it no additional security and the awkward role she played at the Afro-Asian Bandung Conference in championing the cause of Westerns powers may all be interpreted as a part of Democratic Party's efforts to appear as an indispensable ally in order to secure greater aid from the West. ${ }^{43}$

This instrumentalist interpretation of the foreign policy of the Menderes government is, as a matter of fact, cogent. However, Democratic Party's efforts may also be interpreted not for the purpose of appearing as an indispensable ally of the West to secure greater aid, but for the purpose of fulfilling the exigencies of being Western. In can 
also be argued that the Menderes government conflated the modernization of Turkey with the westernization of Turkish foreign policy, with the consequent endorsement of the Western outlook in foreign policy, which seriously conditioned its relations with the non-Western countries. Another factor, it can be argued that conditioned Turkish foreign policy toward the non-Western world was the anti-communist ideology of the Democratic Party leadership, which also influenced its foreign policy thinking. According to Aydin, Turkey's threats to Syria in 1957 to invade "should the Communists, or the Soviet Union, gain control over the Syrian government", among others, was part of its efforts to exacerbate the Communists threat to "get more economic and military aid as well as the result of the Democratic Party's foreign policy thinking, which was essentially anti-Soviet". ${ }^{44}$ However, it can be argued that anti-communism and anti-Sovietism are not completely interchangeable as Aydin suggests but anti-Soviet foreign policy thinking of the Democratic Party was in part a derivative of its anti-communist thinking. As Hale contends, in 1957 during the Syrian Crisis "Adnan Menderes had a more Dullesian-than-Dulles phobia about the dangers of communist penetration in the Middle East, and that his Western allies had to restrain him from taking a more aggressive stance in the region". ${ }^{45}$

The cumulative effect of these ideational factors arguably generated a binary understanding of world politics; for the Menderes government, a country was either with the West, with us, or against the West, against us. Therefore, with reference to the Algerian War of Independence, France was perceived as a fellow Western state whose interests should not have been jeopardized. More importantly, this binary understanding of world politics shaped the foreign policy of the Menderes government toward national liberation movements, or in other words, toward the emerging Third World, and resulted in its persistent condemnation of the policy of neutrality. In other words, with a binary understanding of world politics, the Menderes government could not perceive the emergence of a "third" world and thus was unable to adapt its policies accordingly, and worse yet, its pro-western policies and condemnation of neutrality was to alienate the emerging Third World, and thereby cause serious setbacks for the subsequent Turkish foreign policy-makers. Its policy toward the Algerian War of Independence was an example of this hallmark of the general foreign policy of the Menderes government.

On the other hand, the Algerian War of Independence took place between 1954 and 1962. This was a period between Turkey's entry into NATO in 1952 and the dispatch of the infamous letter of the US President Lyndon Johnson in 1964, two temporal junctures, which arguably characterized the advent and the end of the most Western-oriented period of Turkish foreign policy in the Cold War. There were a couple of elements from Turkey's standpoint, Sander argues, that influenced Turkey's entry into NATO, which were the Soviet threat, the Western-oriented foreign policy, concerns over sustaining economic and military aid, and the preservation of the democratic regime in Turkey. ${ }^{46}$ In addition to these factors, it can be argued, Turkey's entry into NATO not only consolidated the Western-oriented foreign policy of Ankara resulting in its military commitment to an economic 
dependence on the West, but was also construed as the final realization of the long sought objective of Turkey's Westernization; Turkey was finally admitted to the "family" of free Western nations. While NATO membership marked the advent of the most Western-oriented era of Turkish foreign policy in the Cold War, Johnson's letter of 1964 marked the end of it. The letter warned that

your NATO allies have not had a chance to consider whether they have an obligation to protect Turkey against the Soviet Union if Turkey takes a step which results in Soviet intervention without the full consent and understanding of its NATO allies. ${ }^{47}$

If the Johnson Letter shook Turkish policy-makers about the probable adverse consequences of the exclusively Western-oriented foreign policy, the UN General Assembly voting on September 18, 1965 on the Cyprus issue finally awakened them to the actual adverse consequences of the exclusively Western-oriented foreign policy. Forty-eight voted against the Turkish position while only six voted in its favor; 54 states abstained. It was an utter and indisputable evidence of Turkey's isolation in world politics. A Turkish scholar commenting on the voting in December 1965 declared that Turkey woke up from its "sleep of absentmindedness" owing to the Cyprus issue. ${ }^{48}$ In brief, Turkish foreign policy toward the Algerian War of Independence was conditioned by this temporal context with Turkey's entry into NATO in 1952 and the Johnson Letter in 1964 its junctures; two temporal junctures arguably marking the most Western-oriented period of Turkish foreign policy in the Cold War.

\section{Conclusion}

The Menderes government did not extend direct and explicit diplomatic support to "the Algerian problem" despite the fact that the Turkish public took a visible proAlgerian stance. In the related UN General Assembly votings, Turkey voted against the Algerian position in 1955, while abstaining in 1957, 1958, and 1959. Even though Turkey voted in favor of Algerian position in four other votings that took place in February 1957, December 1957, 1960, and 1962, the general perception in Turkey, and Algeria, and in general the Third World, has been critical of its proFrench, pro-Western position. One reason is the fact that while all the resolutions Turkey voted in favor of Algeria passed in the General Assembly, the others Turkey voted against or abstained failed. The Turkish government after the 1960 coup tried to mend ties with non-Western countries and opted to publicly support the Algerian positions, especially in the UN General Assembly. In any case, the common argument has been that there was no excuse for Turkey for its abstention from lending outright diplomatic support for the "Algerian problem". However, in this article, it is argued that the policy attitude of the Menderes government toward the Algerian War of Independence was extensively conditioned by two non-material factors. The first was the foreign policy thinking and outlook of the Menderes 
government, especially characterized by a binary understanding of world politics. The second was the temporal context wherein the Menderes government conducted its foreign policy. Accordingly, an implicit argument in this paper is that non-material and ideational factors were influential in shaping the foreign policy of Turkey, and thus incorporating these factors in analyses of Turkish foreign policy is of import to achieve a better understanding.

\section{Acknowledgements}

I would like to thank Nur Bilge Criss for her valuable comments and criticisms on earlier drafts of this article.

\section{Notes}

1. Matthew Connelly, "Rethinking the Cold War and Decolonization: The Grand Strategy of the Algerian War of Independence," International Journal of Middle East Studies, Vol. 33, No. 2 (2001), pp. $221-245$, p. 233.

2. Atatürk'ün Bütün Eserleri, Vol. 15 (İstanbul: Kaynak Yayınları, 2005), p. 24.

3. Atatürk'ün Bütün Eserleri, Vol. 13 (İstanbul: Kaynak Yayınları, 2005), p. 136.

4. Stephen P. Duggan, "Factors in the Chinese Situation," Political Science Quarterly, Vol. 44, No. 3 (September 1929), pp. 379-96, p. 389. The other event, to Duggan, was "the offer of Bolshevik Russia actively to support China against the other powers." Ibid, p. 389.

5. Faruk Demirtaş, “Cezayirli Lider Mesali Hacı 'Yarı Yarıya Türküm Diyor',” Milliyet, January 30, 1959.

6. Bige Yavuz, Kurtuluş Savaşı Döneminde Türk-Fransız İlişkileri (Ankara: Türk Tarih Kurumu Yayınlar1, 1994).

7. Lütfü Akdoğan, Krallar ve Başkanlarla 50 Yll (İstanbul: ABC Ajansı Yayınları, 2002). Emphasis added.

8. "National independence through restoration of the Algerian state, sovereign, democratic, and social, within the framework of the principles of Islam". For the full text of the proclamation in French, see, Pierre Montagnon, Histoire de 'Algérie: Des Origines à Nos Jours (Paris: Pygmalion, 1998), pp. 267-271.

9. Raymond F. Betts, France and Decolonisation, 1900-1960 (Hampshire: Macmillan, 1991), p. 103.

10. Franz Ansprenger, The Dissolution of the Colonial Empires (London: Routledge, 1989), p. 229. Emphasis in original.

11. Alistair Horne, A Savage War of Peace: Algeria 1954-1962 (New York: New York Review of Books, 2006), p. 98.

12. See, for example, "Fransızlar Cezayirde Tank ve Uçak Kullanmaya Başladılar," Milliyet, November 6, 1954; "Cezayir'de Çarpışmalar Birdenbire Şiddetlendi," Milliyet, November 11, 1954.

13. “Cezayirli Milliyetçiler Dün Fransızların Çemberini Yardı,” Milliyet, November 22, 1954.

14. “Afrika’ya İstiklal Verilemez,” Milliyet, January 20, 1955.

15. Horne (2006), p. 131.

16. "Fransa B. Milletlerdeki Delegelerini Geri Çekti," Milliyet, September 2, 1955.

17. John Ruedy, Modern Algeria: The Origins and Development of a Nation (Bloomington: Indiana University Press, 1992), p. 169.

18. Ergun Göksan, "Dün Fransız Başvekil İle İktisadi Görüşmeler Yapan Menderes Paris’ten Döndü," Milliyet, December 21, 1957.

19. The massage was delivered to the embassies of the four members of the Baghdad Pact, namely Turkey, Pakistan, Iran, and Iraq. See, "Cezayir Bizden Yardım İstedi,” Milliyet, February 1, 1958. 
20. Horne (2006), p. 315.

21. Refi Cevat Ulunay, "Cezayir Kurtulacak," Milliyet, May 19, 1958.

22. Connelly (2001), p. 232.

23. "Cezayir Hakkındaki Tasarıyı B.M. Reddetti," Milliyet, December 15, 1958.

24. Charles-Robert Ageron and Michael Brett (Trans.), Modern Algeria: A History from 1830 to the Present (London: Hurst and Company, 1991), p. 120.

25. Sami Kohen, "Cezayir: Müzakere Safhası," Milliyet, October 15, 1959.

26. Charles C. Cogan, "France, the United States and the Invisible Algerian Outcome," Journal of Strategic Studies, Vol. 25, No. 2 (June 2002), pp. 138-158, p. 144.

27. Berdal Aral, "Fifty Years On: Turkey's Voting Orientation at the UN General Assembly," Middle Eastern Studies, Vol. 40, No. 2 (March 2004), pp. 137-160, p. 139.

28. Mustafa Aydın, "Determinants of Turkish Foreign Policy: Changing Patterns and Conjunctures during the Cold War," Middle Eastern Studies, Vol. 36, No. 1 (January 2000), pp. 103-139, p. 116.

29. Sami Kohen, "Yeni Dış Politikamız," Milliyet, September 22, 1960.

30. "Fransa Cezayir İçin Arabuluculuk Teklifimizi Reddetti," Milliyet, September 27, 1960.

31. Ibid.

32. "Resolutions Adopted on the Reports of the First Committee," UN. http://daccess-dds-ny.un.org/doc/ RESOLUTION/GEN/NR0/153/47/IMG/NR015347.pdf?OpenElement

33. İskender Songur, "B.M. Cezayir İçin Referandum İstiyor," Milliyet, December 17, 1960.

34. "Arap Talebeler Gürsel'e Tasvip Telgrafı Çekti," Milliyet, December 19, 1960.

35. See, for example, the editorial of the daily Milliyet, "Nihayet ... Cezayir'de Barış!" Milliyet, June 30, 1962.

36. Ali Halil, Atatürkçü Dış Politika ve NATO ve Türkiye (İstanbul: Gerçek Yayınevi, 1968), pp. 155-156.

37. Melek Fırat and Ömer Kürkçüoğlu, "Orta Doğu'yla İlişkiler," in Baskın Oran (ed.), Türk Dış Politikası, Vol. I (İstanbul: İletişim Yayınları, 2005), pp. 615-635, p. 634.

38. Kenan Akın, Cezayir'de Fransız Vahşeti ve Ötesi (İstanbul: Derin Yayınları, 2003), p. 53.

39. Bülent Zarif, "Özal: İlişkilerimizin Canlanmasına Çalışacağım," Milliyet, February 5, 1985.

40. Aydin (2000), p. 113.

41. Ömer E. Kürkçüoğlu, Türkiye’nin Arap Orta Doğusu'na Karşı Politikası (1945-1970) (Ankara: Sevinç Matbaas1, 1972), pp. 91-101.

42. Bülent Akarcalı, "Türkiye, Fransa ve Cezayir," Vatan, February 6, 2005.

43. Aydin (2000), p. 112.

44. Ibid.

45. William Hale, Turkish Foreign Policy, 1774-2000 (London: Frank Cass Publishers, 2002), p. 128.

46. Oral Sander, Türk-Amerikan İlişkileri (1947-1964) (Ankara: Sevinç Matbaası, 1979), pp. 62-67.

47. George Harris, Troubled Alliance (Washington, DC: American Enterprise Institute, 1972), p. 115.

48. Ahmet Ş. Esmer, "Uyduluk Siyasetine Son," Milliyet, December 24, 1964.

\section{Notes on Contributor}

Eyüp Ersoy is a PhD candidate in the Department of International Relations, Bilkent University, a research assistant in the Department of International Relations, Yıldırım Beyazıt University, and a research associate at the Center for Security Studies, International Strategic Research Organization. His research interests include power/influence politics, worldviews, identity, and religion in international relations, with specific reference to Middle Eastern politics. He knows English, French, Persian, and Arabic. 